\title{
ESSE VERSUS HABERE - DUALITATEA VOINȚEI UMANE -
}

\section{Ștefan FLORIN*}

\begin{abstract}
Esse versus Habere - The Duality of Human Will. ${ }^{1}$ Man's existence for "to be" or for "to have", depends on how he understands his meaning in the world. This study aims to offer the reader an orthodox view on these two terms, in the hope that it touches the existential substance of contemporary man. When man "stole" deification, possession (of having) became an existential archetype in his physical structure. The serpent bound the soul of the primordial man to a phantasmagoria, a magical deification. The principle of possession expresses man's desire to transform the world into an object of consumption. The fundamental difference between possession and being is that things are worn out by their use, while the being exercised day by day develops to perfection. The need of transcendence, intrinsic to man, has undergone an ontological change that has found naive compensation in the field of technology. Fathers of the desert teaches us to evaluate the world through an unpassionate perception. The evangelical and patristic precepts put in contrast the desire for spiritual growth with a desire possession. This vision of detachment, gives man a sort of discernment that makes him responsible in relation to God, nature and to himself. St. John Chrysostom, recommends the desert as a pedagogical school against passions. The decision of the monks to go to the wilderness was motivated by both the desire to give up the world, possessions and honours, and to fully belong to God. In conclusion, compulsive opening to possessions and objects is mental and not spatial. The contemporary man needs to reflect on what really matters in an ephemeral world.
\end{abstract}

“PhD Student, Faculty of Orthodox Teology „Justinian Patriarch”, at University of Bucharest, Bucharest, Romania.

${ }^{1}$ Studiu realizat sub îndrumarea Pr. Prof. Univ. Dr. Vasile Răducă, care şi-a exprimat acordul pentru publicare. 
Keywords: to be, to have, possession, self-delusion, asceticism, spiritual ascension.

\section{Introducere}

Omul, în evoluția sa, este susținut de două dimensiuni existențiale: a fi și a avea. Tedința sa spre una sau spre cealaltă ține de modul în care își înțelege rostul său în lume. Demersul nostru se inspiră și din lucrarea lui Gabriel Marcel, intitulată: $A$ fi și $a$ avea ${ }^{2}$, respectiv cea a lui Erich Fromm, intitulată: $A$ avea sau a $f i^{3}$, autori care au abordat aceste două concepte, mai ales la nivel psihologic și filosofic. Conform acestor doi autori, tendința omului, în cadrul vieții naturale, este să se identifice cu ceea ce are. Afirmarea ființei este cea dintâi semnificație ontologică pe care porunca divină o revendică omului primordial. Diferența între ființare şi posesie proiectează distanța între dimensiunea ontologică și cea funcțională a omului. Alegerea, ca esență a capacității sale volitive, atrage cu sine întărirea puterii de „,creștere sau de asimilare, care coincide cu libertatea însăși’"’".

Acest studiu își propune să descopere mecanismele care stau la baza opțiunii umane către posesiune, respectiv către existențialism. Una dintre ipoteze suscită ideea că cele două atitudini contrapuse din om, sunt rezultatul unei sciziuni primordiale în mintea sa unificată, fapt ce i-a generat o vedere binoculară, gata să înregistreze structura bipolară a lumii. Pe de altă parte, am presupus că noile tehnologii și conținuturile culturale preschimbă, într-un mod superficial, natura profundă a omului. Astfel, adoptarea unei conduite consumeriste, sub titulatura lui homo aeconomicus, îl îndepărtează pe om de înclinaţiile sale morale şi îi încețoșează conștiința, gândind numai în termenii utilitarismului.

Soluţia preventivă, strategică, împotriva unei perspective pesimiste în privința omului actual, evidențiază necesitatea unei viziuni înnoite, a unei atitudini metanoice, al căror obiectiv este autoreflecția şi conștientizarea adevăratelor priorități într-o lume efemeră. Totodată, e necesar ca omul actual să se întoarcă la viețile Părinților creștini ai

${ }^{2}$ Gabriel Marcel, A fi și a avea, trad. Ciprian Mihali, Cluj, Edit. Biblioteca Apostrof, 1997.

${ }^{3}$ Erich Fromm, A avea sau a fi, trad. Octavian Cocoș, București, Edit. Trei, 2013.

${ }^{4}$ Gabriel MARCEL, A fi și a avea, p. 100. 
deșertului, ale căror viață și asceză ne oferă noi modalități de a confrunta nevoile compulsive de câștig, de recompensă socială și de autodeificare.

\section{Simțul ființării și simțul proprietății}

Din grădina Edenului, omul originar și-a dezvoltat două atitudini contrapuse: a avea şi a fi, adică posesiunea și ființarea. Conceptul $a$ avea a scindat mintea omului și a creat două perspective asupra relaţiei cu Dumnezeu, cu lumea și cu el însuşi. Existenţa ghidată de principiul posesiunii, exprimă dorinţa omului de a transforma lumea şi chiar pe Dumnezeu într-un obiect de consum, într-o proprietate. Din această perspectivă, istoria omenirii nu e decât ,o istorie a luptei pentru «a fi»» sau «a avea»" propriei ființe, înglobând polaritatea lumii în propria structură. Astfel, există permanent în om un conflict intrapsihic între ce ar vrea să fie la modul ideal și ce este el la modul real. Omul apare, așadar, ca o figură scindată și indecisă, permanent aflată în dilema unei voințe duale. Aristotel a intuit foarte bine această dualitate arhetipală în om, oferind exemplul unui câine flămând, incapabil să aleagă între două porţii de mâncare, iar mai târziu, Jean Buridan (în sec. XIV) născocește fabula măgarului însetat şi înfometat, care risca să moară indecis între o găleată cu apă şi un vas cu ovăz

Mintea omului care se fixează pe ,,a avea”, mimează caracteristicile lucrurilor materiale, fixe și imobile, dispunând de o funcționalitate inflexibilă și rigidă. În contrast, a deveni ființial desemnează a-și însuși un mobil de transformare, înseamnă a deveni convertibil. Meister Eckhart numea fiinţarea un proces de „fierbere“, de „,naştere“7

Diferența fundamentală între posesie și ființare este aceea că lucrurile se uzează prin folosirea lor, pe când a exersa ființa zi de zi,

5 ,A avea mai întâi strictul necesar, a avea apoi ceea ce au şi alţii, şi după aceea să ai ceea ce nu are nimeni" (Constantin DulCAN, Inteligența materiei, Cluj-Napoca, Edit. Eikon, 2009, p. 308).

${ }^{6}$ Paul Edwards (ed.), Encyclopedia of Philosophy, Vol. I, Macmillan Publishers Ltd, 1967, p. 428, apud Irvin D. YALOM, Psihoterapia existenţială trad. Bogdan Boghiţoi, București, Edit. Trei, 2012, p. 371.

${ }^{7}$ Meister Eckhart, Cetățiia din suflet. Predici germane, trad. Sebastian Maxim, Iași, Edit. Polirom, 2003, p. 54. 
înseamnă a o amplifica, a o dezvolta spre perfecționare. Prin propria uzură sufletească, omul își procură un plus de ființă, de abilitate. Simbolul biblic al acestui paradox este Rugul aprins care nu se mistuia în flăcări. În ființare nu există frica de pierdere, pentru că „ceea ce se cheltuieşte nu se pierde, ci, dimpotrivă, se păstrează"

Cert este faptul că, la un moment dat, omul se află la o bifurcație a opțiunii: spre materialitate sau spre spiritualitate. Allen Wheelis afirma că puterea de a renunța la una dintre opțiuni, face dovada unui curaj existențial demn de apreciat și dovada maturității personale ${ }^{9}$.

Pentru o hotărâre nezdruncinată, omul ar putea apela la un subterfugiu foarte eficient: gândul la moarte ${ }^{10}$. Prin perspectiva morții, putem dobândi o conștientizare mai eficientă asupra efemerității obiectelor lumii acesteia ${ }^{11}$. Hristos ne porunceşte căutarea împărăţiei lui Dumnezeu şi a dreptăţii Sale mai întâi $(a f i)$, iar după aceea, toate celelalte, adică bunurile pământeşti ( $a$ avea), se vor adăuga lor (Mt. 6, 33).

\section{Iluzia autodeificării versus percepția nepătimașă față de lume}

În starea paradisiacă, primul om şi-a dezvoltat o iluzie în jurul conceptului îndumnezeire, făurită, e adevărat, cu ajutorul șarpelui. Şarpele a legat mintea omului de o fantasmagorie, de o îndumnezeire magică, care putea fi însușită printr-o voință despotică. Până astăzi, omul este tributar acestei conduite decăzute, creându-și o mreajă în jurul sinelui, prin acumularea de bunuri (valori personale, posesiuni, reputație, putere socială), în speranța că acestea îl vor propulsa către autodeificare.

\footnotetext{
${ }^{8}$ Erich Fromm, A avea sau a fi, p. 143.
}

9 „Maturitatea şi curajul înseamnă în bună parte capacitatea de a renunţa la una dintre opțiuni, iar o bună parte a înţelepciunii este dată de capacitatea de a găsi noi căi care ne vor da posibilitatea de a renunța cât mai puţin” (Allen WHEELIS, „Will and Psychoanalysis", în Journal of the American Psychoanalysis Association, Vol. 4, $2 /$ 1956, p. 285-303, apud Irvin D. YALOM, Psihoterapia existenţială, p. 371).

${ }^{10}$ Multe texte din Sfânta Scriptură subliniază că această lume trebuie tratată cu o anumită reținere, din cauza iluziei pe care o poate transmite: „Nu iubiţi lumea, nici cele ce sunt în lume. Dacă cineva iubeşte lumea, iubirea Tatălui nu este întru el” (I In. 2, 15); „Căci chipul acestei lumi trece" (I Cor. 7, 31).

${ }^{11}$ Pierre HADOt, Ce este filosofia antică ?, trad. George Bondor și Claudiu Tipuriţă, Iași, Edit. Polirom, 1997, p. 230-231. 
Procesul de autolatrie își are originea în pulsiunile iubitoare de plăcere (philedonia). Acestea „mistuie și epuizează funcțiile sufletului”"12. Deși omul rămâne o creatură, în ipostaza autodeificării, el respinge sau neagă existența unei ființe superioare, creatoare. Această atitudine nihilistă, îl încurajează să trateze lumea și pe ceilalţi într-un mod dominator, care îl conduce inevitabil spre obsesia compulsivă de a poseda câștiguri materiale, o iluzie care îi va absorbi toată iubirea și energia. Jean Bremond afirmă că ,iluziile și orbirile de bunăvoie stau la originea numeroaselor pervertiri ale simţului de dreptate"13.

Căzând pradă pasiunilor sale iraționale care îi ,violontează conștiința" ${ }^{14}$, discernământul alterat al omului lasă loc unei iluzii autoamăgitoare. Sf. Grigorie de Nyssa evidențiează acest lucru în Comentariu la Psalmi: „Ceea ce năzuieşte omul în această viaţă există doar în gândurile sale, nu şi în realitate: opinie, cinste, demnitate, renume, fericire, toate reprezintă doar o lucrare a pânzei de păianjen a acestei vieţi..."15. Autoiluzionarea nu e doar o formă de cecitate a intelecției, ci apare și ca o formă de nebunie în raport cu creaţia.

Adrian Mihalache afirmă că există posibilitatea detaşării emoționale în privința lucrurilor care ne înconjoară, dacă nutrim o percepție nepătimașă față de lume și dacă ne exersăm starea de autocontrol, care ne conferă o responsabilizare mai mare față de natură ${ }^{16}$. Primul aspect pozitiv în funcționalitatea omului, atunci când își conștientizează poziţia față de lume și față de sine însuși, este claritatea conștiinței. De altfel, viziunea detaşată îi procură omului un soi de

${ }^{12}$ Panayotis Nellas, Omul, animal îndumnezeit, trad. Ioan I. Ică jr, Sibiu, Edit. Deisis, 2009, p. 183.

${ }^{13}$ Jean BRÉMOnd, Părinții pustiei, trad. Marinela Bojin, București, Edit. Nemira, 2010, p. 154.

${ }^{14}$ Mircea Eliade, Patañjali și Yoga, trad. Walter Fotescu, București, Edit. Humanitas, 2013, p. 53.

${ }^{15}$ Sf. Grigorie DE NYSSA, „Comentariu la Psalmi”, în P.G. (Patrologia Graeca editată de J. P. Migne), vol. 44, col. 464-465 [trad. rom. Sf. Grigorie de Nyssa „La titlurile psalmilor", în Seria PSB, Scrieri, partea a II-a, Bucureşti, EIBMBOR, 1998].

16 Adrian Sorin MiHALACHE, „Stiinţa interiorităţii şi cuantificarea eului. Teologia ortodoxă şi neuroştiinţele despre viaţa lăuntrică în era dominaţiei tehnologiilor”, în Marin BĂLAN (ed), Valentin MUREȘAN (coord.), Etica în știință, religie și societate, București, Edit. Universității din București, 2014, p. 113. 
discernământ, acest filtru al dorințelor și al impulsurilor egoiste, cu ajutorul căruia reușește să respecte mai bine legile naturii și ale vieții. De pildă, pentru înțelepții stoici, lucrurile și obiectele din lume aveau, cu necesitate, o finalitate etică. În urma interacțiunii cu acestea, omul suferea o „transformare interioară, o mutație a viziunii" ${ }^{17}$. Acțiunea asupra lumii, modelează, în primul rând, interiorul celui care acționează.

\section{Lăcomia mentală și conduita consumeristă ale omului actual}

Baruch Spinoza făcea o distincție cu privire la dorințele umane, clasificate de el în active şi pasive. Cele active sunt înrădăcinate în starea naturală a firii umane și depind de voinţa autentică a omului, cele pasive sunt cauzate de condiţiile perturbatoare, care anulează facultatea volitivă a omului. Astfel, potrivit acestui autor, ,activitatea, raţiunea, libertatea, bunăstarea, bucuria şi autoperfecţionarea sunt legate într-un mod inseparabil — aşa cum sunt şi pasivitatea, iraţionalitatea, sclavia, tristeţea, lipsa de putere şi toate tendinţele contrare nevoilor naturii umane" 18 .

Dorința nestăvilită de posesie, lăcomia, pare să fie, după unii autori creștini, cea mai mare pasiune înrobitoare. Iubirea de argint devine cursa unor ,pofte nebunești și foarte vătămătoare, pentru că cufundă pe oameni în ruină și în pierzare" ${ }^{19}$. Dezlipirea de cele materiale are loc, mai întâi, la nivel mental, fiindcă lăcomia sau pofta rămân, adeseori, obsesii mentale. Jean Brémond povestește despre unii monahi care, neavând nimic al lor în mănăstiri, au preferat sihăstria din dorința de a-și păstra puținul doar pentru ei ${ }^{20}$. Iar avva Ioan Colov spunea că: „Dacă un monah are în sufletul

${ }^{17}$ Pierre HAdot, Ce este filosofia antică?, p. 253.

${ }^{18}$ Baruch SPINOZA, Etica demonstrată după metoda geometrică și împărțită în cinci părți, Partea a patra, Adaos la cap. II, trad. Alexandru Posescu, București, Edit. Humanitas, 2006, prop. XL, XLII.

${ }^{19}$ Pavel Chirilă, Teofan Munteanu, Psihologia in Sfintele Scripturi, Bucureşti, Edit. Christiana, 2012, p. 252.

${ }^{20}$ Jean BRÉMOND, Părinții pustiei, p. 155. Sf. Ioan Cassian observa cât de dezgustător e faptul că există monahi care au păăsit poate avuții uriașe în lume, apoi s-au retras în deșert, bânduiți de pofta bunurilor lumii, și s-au atașat de niște bagatele: o rogojină, un coş, o sacoşă, un manuscris, un fus, un ac, o trestie de scris (Ioan CASSIEN, Institutions, 7,7, în S.C. (Sources Chretiennes, ed. J. C. Guy) 109, Paris, 1965, [trad. rom. V. Cojocaru şi D. Popescu, PSB 57, 1990, p. 109-265], apud Lucien Regnault, Viața 
său un lucru al lui Dumnezeu, poate rămâne în chilia sa chiar fară să aibă nici un lucru al lumii acesteia. Şi încă, dacă un om are lucruri ale lumii acesteia fără a le avea pe cele ale lui Dumnezeu, atunci el rămâne în chilie pentru lucrurile acestei lumi" 21 . Unul dintre motivele hotărârii de a pleca în pustie era pentru monahi și acela de a-și întări puterea de renunțare la lume, la lucruri, la tot ce posedau. Virtutea sărăciei depline și a răbdării lipsurilor erau, în primul rând, rezultatul unui proces interior greu de atins.

În actualitate, observăm că homo aeconomicus este o creație a civilizației, apărută recent în istoria omenirii. Despre aceste modificări ontologice în ființa omului, ca urmare a tehnologizării, a vorbit și filosoful Roman Ingarden. Acest autor înțelege tehnologia ca pe o compensație a omului modern în fața regresiei sale în planul transcendenței. Autorul consideră că această mutație, la nivel existențial, îi schimbă omului structura profundă: „Omul se deschide către obiecte de acest fel şi încearcă să le înţeleagă, însă îl şi afectează şi uneori îi modifică profund viaţa spirituală şi, într-o anumită măsură, viaţa trupească"22.

Reducând persoana umană numai la o conduită productivă și consumeristă, înseamnă o reală diminuare a personalității ei profunde. Suntem de părere că nevoia omului de transcendență, deși pervertită, nu a sucombat întru totul. Mai degrabă, și-a satisfăcut-o prin direcționarea (greșită) către tehnică și cultură.

\section{Asceza, un ,barometru” autentic cu privire la valorile acestei lumi}

În faţa descătușărilor poftelor nebunești, se impune „un jug”, ,o înfrânare", ca acțiuni ale voinței. Latinescul jüngere, -jugum (jug), englezescul yoke (a lega laolaltă, a ţine strâns, a înhăma), caracterizează

cotidiană a Părinţilor deşertului în Egiptul secolului IV, trad. Ioan I. Ică jr, Sibiu, Edit. Deisis, 2013, p. 120.

${ }^{21}$ S.P. (Les Sentences des Pères du désert) collection alphabétique, Solesmes, 1981, 959

(Suppl. Ioan Colov 40), apud Lucien RegnAUlt, Viața cotidiană a Părinţilor deşertului în Egiptul secolului IV, p. 121.

22 Roman Ingarden, Man and Value, Washington DC, Catholic University of America Press, 1983, p. 19. 
„orice tehnică de asceză"23. Meister Eckhart obişnuia să vorbească în Predicile sale despre «Gelassenheit» (lăsare), adică eliberarea pe care omul trebuie să o asume în raport cu el însuşi şi cu toate lucrurile. Omul trebuie să devină simplu ca ,să se insereze în Binele simplu care e Dumnezeu"24.

Se pare că motivaţiile extrinseci ale omului, au devenit surse carei alimentează orgoliul, nevoia de statut social și de stimă de sine, încât acesta se supune impresiilor despre sine și devine dependent de recompensă socială. În limbaj filocalic, termeni precum: „mărire deșartă, mândrie" exprimă exact această denaturare a omului, căzut în capcana autoestimației. Sf. Ioan Gură de Aur oferea sfaturi duhovnicești foarte practice împotriva măririi deșarte: ,Tu, omule, fie că eşti de neam mare, fie că ai o slujire înaltă, mergi în pustie şi vezi cum sunt socotite ca nimic tot luxul şi deşertăciunile acestei lumi, [...] Doar simpla lor vedere stinge trufia celor mândri şi-l îndreaptă chiar şi pe cel mai nărăvit dintre oameni" 25 .

Pentru mulți contemporani ai Sf. Ioan, calea pustiului devenea temporar sau definitiv o școală pedagogică pentru propriile patimi. Acolo, în acea zonă deșertificată, omul leapădă orice artificiu și orice rang al vieții sociale; rămâne ,despuiat” de orice onor.

Dacă în civilizație, piața economică controlează și reglează prețul unui lucru ${ }^{26}$, în pustie nici măcar valoarea biologică a omului nu mai are relevanță, fiindcă cine vine în acest loc neprielnic vieții, trebuie să-și asume amânarea satisfacerii unor nevoi de ordin vital şi regimul de minimă supraviețuire. Astfel, îndemnul Domnului: ,Du-te, vinde tot ce ai [...] apoi vino şi urmează-Mi Mie" (Mt. 19, 21) face sens când vine vorba de vocaţia anahoretului care aleargă în pustie, gata să-L urmeze ,gol” pe Hristos.

${ }^{23}$ Mircea Eliade, Patañjali și Yoga, p. 9.

${ }^{24}$ Meister ECKHART, Traites et sermons, traduction et presentation par Alain de Libera, Paris, Flammarion, 1995, p. 221, apud André SCRIMA, Funcția critică a credinței, trad. Anca Manolescu, București, Edit. Humanitas, 2011, notă de subsol, p. 49.

${ }^{25}$ Sf. Ioan Gura De Aur, Omilii la Matei, LXX, în P.G. (Patrologia Graeca editată de J. P. Migne), vol. 58, col. 654, apud Jean BREMOND, Părinții pustiei, p. 159.

26 „Preţul este un mijloc de a controla nepotrivirea foarte reală între ce este disponibil şi cererea pentru acel ceva. Preţul introduce restricţii şi creează un fel de ordine în accesul la lucruri” (Antonio DAMASIO, Sinele. Contruirea creierului conștient, trad. Doina Lică, București, Edit. Humanitas, 2016, p. 59). 
Există povestiri despre părinți eremiți care au urmat acestei goliciuni, ad litteram. De exemplu, avva Macarie găsise în adâncul deşertului doi monahi goi bând apă dintr-o baltă împreună cu dobitoacele ${ }^{27}$. Luând la cunoștință despre astfel de cazuri, nu putem deduce că părinții deșertului ar fi fost niște exhibiţioniști, ci mai degrabă ei arătau prin această dezgolire a trupului, finalitatea ascezei și a luptei lor: despuierea de tot ce este pământesc, așa cum o mărturisesște Avva Amomoi, care îi cere ucenicului său, Ioan, să-și lepede veșmintele sale, pentru a demonstra vizitatorilor cum devine cineva monah: „Dacă omul nu se despoaie aşa de cinstea şi lauda acestei lumi, nu poate să se facă monah" 28 .

Evanghelia după Matei ne-a oferit un episod în care averea sau, mai degrabă, nedezlipirea de ea, este opusă desăvârșirii spirituale. Tânărul bogat, deși era un om conștiincios al poruncilor vechi-testamentare și cu o predispoziție naturală spre ascensiunea spiritului, totuși, la îndemnul Mântuitorului de a vinde toate ale sale săracilor și apoi să vină să-L urmeze, „a plecat întristat, căci avea multe avuţii” (Mt. 19, 16-22). Privarea de avuții îl plasează pe om ,întristării lumii”, iar întristarea lumii îi aduce moarte ${ }^{29}$. Hristos încuraja privațiunile ca lucrare terapeutică împotriva robiei față de patimi și față de bunurile materiale.

\section{Concluzii}

În concluzie, observăm că dependența față de lucruri materiale nu depinde neapărat de loc, cât mai ales de mintea omului. Bunurile pământești și grijile lumești au fost permanent o ,,piatră de poticneală” în zborul sufletului către cer. Riscând să rămână submisiv materiei și tentaţiilor din civilizație, anahoretul s-a sustras total din lume în singurătatea deșertului tocmai din dorința de a aparține total lui

27 S.P. (Les Sentences des Pères du désert), collection alphabétique, Solesmes, 1981, 456 (Macarie 3), [trad. rom. Patericul, Ed. a V-a, Alba Iulia, Edit. Episcopiei Alba Iuliei, 1990, p. 7-240 (colecţia alfabetică)], apud Lucien REGNAULT, Viața cotidiană a Părinţilor deşertului în Egiptul secolului IV, p. 79.

${ }^{28}$ Cf. Apophtegmes traduits du copte, în S.P. (Les Sentences des Pères du désert), 3e recueil, Solemes, 1976, p. 139-194, (avva Amomoi 337), apud Lucien REGNAULT, Viaţa cotidiană a Părinţilor deşertului în Egiptul secolului IV, p. 80.

${ }^{29}$ Vezi: II Cor. 7, 10. Şi în altă parte: „Oricine dintre voi care nu se leapădă de tot ce are, nu poate să fie ucenicul Meu” (Lc. 14, 33). 
Dumnezeu. El și-a asumat o moarte benevolă în relație cu orice posesiune și, de aceea, el nu mai are nevoi obișnuite.

Pe parcursul acestei lucrări, am înțeles că preceptele evanghelice și patristice, pun în antiteză dorința de creștere spirituală cu dorința de posesiune, astfel că modul $a \mathrm{fi}$ e transcendent faptului-de-a-avea ${ }^{30}$.

Am atras atenția asupra modului de existență $a f i$ care, prin exersarea lui, aduce o dilatare a ființei umane, înțeleasă ca înfrumusețare a naturii sale. Existența bazată pe $a$ avea obturează capacitatea omului de a privi lumea printr-o lentilă curată, identificându-și propriul sine cu ceea ce posedă. Deși pare că noile tehnologii aduc schimbări majore asupra personalității omului și asupra structurii sale profunde, totuși nu putem rămâne atât de pesimiști în privința omului contemporan, ci sperăm că poate ajunge la o viziune nepătimașă și nemercantilă, dacă apelează la viețile Părinților din pustie care demonstrează cu atâta abnegație renunțarea la artificiile lumii și îmbrățișarea nevoilor profunde ale umanității: iubirea, compasiunea, smerenia. Rezultă că omul actual are nevoie să reflecteze mai mult cu privire la adevăratele sale nevoi și la ceea ce contează cu adevărat într-o lume efemeră.

\section{Referințe bibliografice:}

1. BREMOND, Jean, Părinţii pustiei, trad. Marinela Bojin, București, Edit. Nemira, 2010;

2. Chirilă, Pavel, Munteanu, Teofan, Psihologia in Sfintele Scripturi, Bucureşti, Edit. Christiana, 2012;

3. Damasio, Antonio, Sinele. Contruirea creierului conștient, trad. Doina Lică, București, Edit. Humanitas, 2016;

4. DulCAN, Constantin, Inteligența materiei, Cluj-Napoca, Edit. Eikon, 2009;

5. ECKHART, Meister, Cetăţuia din suflet. Predici germane, trad. Sebastian Maxim, Iași, Edit. Polirom, 2003;

6. Eliade, Mircea, Patañjali şi Yoga, trad. Walter Fotescu, București, Edit. Humanitas, 2013;

7. Fromm, Erich, A avea sau a fi, trad. Octavian Cocoș, București, Edit. Trei, 2013;

${ }^{30}$ Gabriel MARCEL, A fi și a avea, p. 100. 
8. Sf. Grigorie DE NYSSA, „Comentariu la Psalmi”, în P.G. (Patrologia Graeca editată de J. P. Migne), vol. 44;

9. HADOT, Pierre, Ce este filosofia antică?, trad. George Bondor și Claudiu Tipuriță, Iași, Edit. Polirom, 1997;

10. INGARDEN, Roman, Man and Value, Washington DC, Catholic University of America Press, 1983;

11. MARCEL, Gabriel, A fi și a avea, trad. Ciprian Mihali, Cluj, Edit. Biblioteca Apostrof, 1997;

12. MihalaCHE, Adrian Sorin, „Ştiinţa interiorităţii şi cuantificarea eului. Teologia ortodoxă şi neuroştiinţele despre viaţa lăuntrică în era dominaţiei tehnologiilor", în Marin BĂLAN (ed), Valentin MUREŞAN (coord.), Etica în știință, religie și societate, București, Edit. Universității din București, 2014, p. 103 -139;

13. Nellas, Panayotis, Omul, animal îndumnezeit, trad. Ioan I. Ică jr, Sibiu, Edit. Deisis, 2009;

14. Regnault, Lucien, Viața cotidiană a Părinţilor deşertului în Egiptul secolului IV, trad. Ioan I. Ică jr, Sibiu, Edit. Deisis, 2013;

15. SCRIMA, André, Funcția critică a credinței, trad. Anca Manolescu, Bucureşti, Edit. Humanitas, 2011;

16. SPINOZA, Baruch, Etica demonstrată după metoda geometrică şi impărțită în cinci părți, Partea a patra, Adaos la cap. II, trad. Alexandru Posescu, București, Edit. Humanitas, 2006;

17. Yalom, Irvin D., Psihoterapia existenţială, trad. Bogdan Boghiţoi, București, Edit. Trei, 2012. 